\title{
Gastrointestinal and external parasites of the Variable hawk Geranoaetus polyosoma (Accipitriformes: Accipitridae) in Chile
}

Parasitas gastrointestinais e externos do Falcão Variável Geranoaetus polyosoma (Accipitriformes: Accipitridae) de Chile

Alexandra Grandón-Ojeda ${ }^{1}$; Patricio Cortés ${ }^{1}$; Lucila Moreno²; John Mike Kinsella ${ }^{3}$; Armando Cicchino ${ }^{4}$; Carlos Barrientos'; Daniel González-Acuña ${ }^{1}$ (D)

\author{
${ }^{1}$ Laboratorio de Enfermedades y Parásitos de Fauna silvestre, Facultad de Ciencias Veterinarias, Universidad de Concepción, Chillán, Chile \\ ${ }^{2}$ Facultad de Ciencias Naturales y Oceanográficas, Universidad de Concepción, Concepción, Chile \\ ${ }^{3}$ Helm West Lab, Missoula, Montana, United States of America \\ ${ }^{4}$ Universidad Nacional de Mar del Plata, Mar del Plata, Argentina \\ ${ }^{5}$ Escuela de Medicina Veterinaria, Universidad Santo Tomás, Concepción, Chile
}

Received February 7, 2019

Accepted May 5, 2019

\begin{abstract}
Information about parasites associated with diurnal raptors from Chile is scarce. Between 2006 and 2017, a total of 15 specimens of the Variable hawk, Geranoaetus polyosoma (Quoy \& Gaimard, 1824) were collected, 14 of them from different localities in the Biobío region and one specimen from the Valparaíso region. An external examination of the plumage was made to collect ectoparasites, and necropsies were performed, focusing primarily on the gastrointestinal tract. Chewing lice (Phthiraptera) were found on five (33.3\%) of the birds corresponding to three species: 97 specimens of Degeeriella fulva (Giebel, 1874), six specimens of Colpocephalum turbinatum Denny, 1842 and nine belonging to an unidentified species of the genus Craspedorrhynchus Kéler, 1938. Endoparasites found in three (20\%) of the birds included round worms (Nematoda) of the genus Procyrnea Chabaud, 1958, and spiny-headed worms (Acanthocephala) of the genus Centrorhynchus Lühe, 1911. The species Colpocephalum turbinatum and the genera: Craspedorrhynchus sp., Procyrnea sp. and Centrorhynchus sp. are new records for the Variable hawk.
\end{abstract}

Keywords: Parasites, lice, Nematoda, Acanthocephala, birds, raptors.

\section{Resumo}

No Chile, informaçôes sobre parasitas associados a aves de rapina diurnas são escassas. Entre os anos 2006 e 2017, um total de 15 espécimes do Falcáo Variável Geranoaetus polyosoma (Quoy \& Gaimard, 1824) mortos, foram examinados, 14 deles provenientes de diferentes localidades da região do Biobío e um espécime na região de Valparaíso. Um exame externo da plumagem foi feito para coletar os ectoparasitas e necropsias do tracto gastrointestinal para coleta de endoparasitas. Cinco aves (33,3\%) foram positivas para três espécies de piolhos (Phthiraptera): 97 espécimes de Degeeriella fulva (Giebel, 1874), seis espécimes de Colpocephalum turbinatum Denny, 1842 e nove espécimes não identificados do gênero Craspedorrhynchus Keler, 1938. Endoparasitas foram encontrados em três aves (20\%), incluindo vermes redondos (Nematoda) do gênero Procyrnea Chabaud, 1958, e vermes achatados (Acanthocephala) do gênero Centrorhynchus Lühe, 1911. As espécies Colpocephalum turbinatum e os dos gêneros Craspedorrhynchus, Centrorhynchus e Procyrnea corresponderam a novos registros para o Falcão Variável.

Palavras-chave: Parasitas, piolhos, Nematoda, Acanthocephala, aves, raptores.

\section{Introduction}

Parasites play important roles in trophic chains (DUNNE et al., 2013) and in the regulation of community composition (WOOD et al., 2007). It is also thought that the loss of the parasitic fauna can

*Corresponding author: Daniel González-Acuña. Facultad de Ciencias Veterinarias, Universidad de Concepción, Casilla, 537, Chillán, Chile. e-mail: danigonz@udec.cl. predispose hosts to infections by generalist parasites or emerging diseases (DUNN et al., 2009). The Variable hawk, Geranoaetus polyosoma (Quoy \& Gaimard, 1824), is a medium-sized accipitriform with a body length between 45 and $62 \mathrm{~cm}$ (CHESTER, 2008), with at least 27 different morphs described according to its very variable plumage due to age (JARAMILLO, 2005). It has a wide 
Neotropical distribution (FERGUSON-LEES \& CHRISTIE, 2001), from the central Andes of Colombia to Tierra del Fuego (VAURIE, 1962). In Chile, the Variable hawk can be seen in a large section of the continental territory, from the coast up to 5000 meters above sea level in the Andes mountain range (JARAMILLO, 2005). It lives in all types of environments, including suburban and scrub areas with or without trees, cultivated fields, river edges, foothill forests, mountain ridges and ranges covered with Nothofagus trees (FERGUSON-LEES \& CHRISTIE, 2001). The prey of the Variable hawk is diverse, including the European hare (Lepus europaeus Pallas, 1778), European rabbit (Oryctolagus cuniculus (Linnaeus, 1758)) (MONSERRAT et al., 2005), and different species of native rodents, birds and insects (FIGUEROA-ROJAS et al., 2003; TREJO et al., 2006). In Chile, only the chewing louse species Degeeriella fulva (GIEBEL, 1874) has been collected from $G$. polyosoma in the following locations: Nueva Aldea, Angol, Linares, Alhué, Aconcagua, Longotoma, Colina and Santa Clara (MORENO \& GONZÁLEZ-ACUÑA, 2015). No reports of endoparasites from the Variable hawk in Chile have been published (MORENO \& GONZÁLEZ-ACUÑA, 2015). The aim of this research project was to study and increase knowledge of the parasitic fauna of the Variable hawk.

\section{Materials and Methods}

A total of 15 carcasses of Geranoaetus polyosoma collected between 2006 and 2017 from different locations in central Chile, ranging from the Valparaíso region in the north $\left(33^{\circ} 03^{\prime} 47^{\prime \prime} \mathrm{S}, 71^{\circ} 38^{\prime} 22^{\prime \prime W}\right)$ to the Biobío region (36 $\left.46^{\prime} 22^{\prime \prime} \mathrm{S}, 73^{\circ} 03^{\prime} 47^{\prime \prime W}\right)$ in the south, were examined externally and internally for parasites. The cause of death of the birds varied from collisions with vehicles and electric cables, poaching and poisoning. The birds were kept individually in separate bags, frozen and then necropsied. Ectoparasites were collected by inspecting the plumage visually and were subsequently preserved in $70 \%$ ethanol. Lice were cleared and slide-mounted in Canada balsam, as described by Palma (1978) and Price et al. (2003). The collection and preparation of helminths followed the techniques proposed by Kinsella \& Forrester (1972). Roundworms and spinyheaded worms were cleared temporarily in lacto-phenol, and were returned to the preservative after their identification.

The identification of lice was made using keys and descriptions published by Giebel (1874), Denny (1842), Clay (1958), Price \&
Beer (1963) and Price et al. (2003). Keys published by Chabaud (1975) were used for the identification of roundworms, and a key in Amin (1987) for the identification of spiny-headed worms. The GIMP 2.8.22 program was used to edit all the figures.

All the specimens studied are deposited in the collection at the Laboratory of Parasites and Diseases of Wildlife, Faculty of Veterinary Science, University of Concepción, Chillán, Chile.

\section{Results and Discussion}

Eight of the 15 birds examined were positive for at least one parasite (53.3\%). Prevalence for ectoparasites was 33.3\% with five birds infested, while prevalence for endoparasites was $20 \%$ with only three birds infected (see Table 1). Three species of lice (Insecta: Phthiraptera) belonging to three genera, as well as two species of parasitic worms belonging to two phyla (Nematoda and Acanthocephala) were recorded.

\section{Phthiraptera}

A total of 97 specimens of Degeeriella fulva (Figures 1 and 2) was collected on three (20\%) of the Variable hawks studied. The genus Degeeriella Neumann, 1906 comprises a total of 41 species parasitic on diurnal raptors of the families Falconidae and Accipitridae with a relatively uniform morphology, which makes their identification difficult (CLAY, 1958; PRICE et al., 2003; MARTÍN-MATEO, 2009). Degeeriella fulva has a worldwide distribution parasitizing a broad spectrum of hosts, having been collected from individuals in captivity and in the wild (INCI et al., 2010; OLIVEIRA et al., 2011). Moreno \& González-Acuńa (2015) reported Degeeriella fulva on the Variable hawk from several localities in Chile; it has also been found on the Long-legged Buzzard (Buteo rufinus (Cretzschmar, 1827)) and the Common Buzzard (Buteo buteo (Linnaeus, 1758)) in Turkey and Portugal, respectively (DIK, 2006; TOMÁS et al., 2016), the Red-tailed hawk (B. jamaicensis (Gmelin, 1788)) in the USA and México (MORISHITA et al., 2001; OLIVEIRA et al., 2011), and on the Mountain hawk-eagle (Spizaetus nipalensis Hodgson, 1836) in Japan (YOSHINO et al., 2012). Degeeriella fulva was the most abundant species collected in this study.

Table 1. Summary and parasitological descriptors of external and gastrointestinal parasites found from 15 Variable hawks in Chile.

\begin{tabular}{|c|c|c|c|c|c|c|}
\hline Species & Prevalence (\%) & Range & Mean intensity & $\begin{array}{c}\text { Mean } \\
\text { abundance }\end{array}$ & $\begin{array}{c}\text { Number of } \\
\text { parasitized } \\
\text { birds }\end{array}$ & $\begin{array}{l}\text { Total of } \\
\text { parasites }\end{array}$ \\
\hline \multicolumn{7}{|l|}{ Phthiraptera: Ischnocera } \\
\hline Degeeriella fulva & 20 & $0-83$ & 32.3 & 6.47 & 3 & 97 \\
\hline Craspedorrhynchus sp. & 6.7 & $0-9$ & 9 & 0.6 & 1 & 9 \\
\hline \multicolumn{7}{|l|}{ Phthiraptera: Amblycera } \\
\hline Colpocephalum turbinatum & 13.3 & $0-3$ & 3 & 0.4 & 2 & 6 \\
\hline \multicolumn{7}{|l|}{ Nematoda: Spirurida } \\
\hline Procyrnea sp. & 13.3 & $0-10$ & 5.5 & 0.7 & 2 & 11 \\
\hline \multicolumn{7}{|c|}{ Acanthocephala: Polymorphida } \\
\hline Centrorhynchus sp. & 6.7 & $0-3$ & 3 & 0.2 & 1 & 3 \\
\hline
\end{tabular}




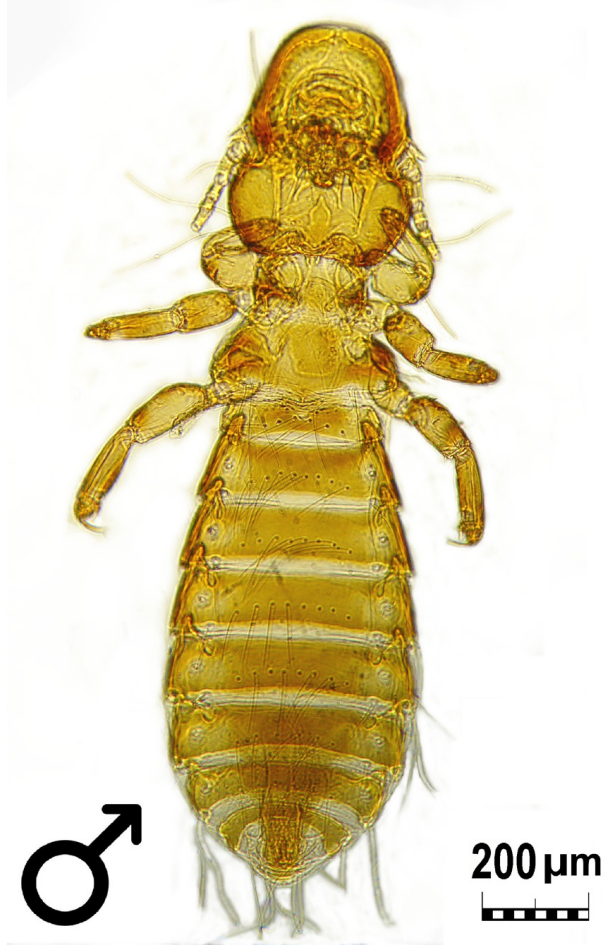

Figure 1. Degeeriella fulva. Male. Ventral view. Magnification 100X.

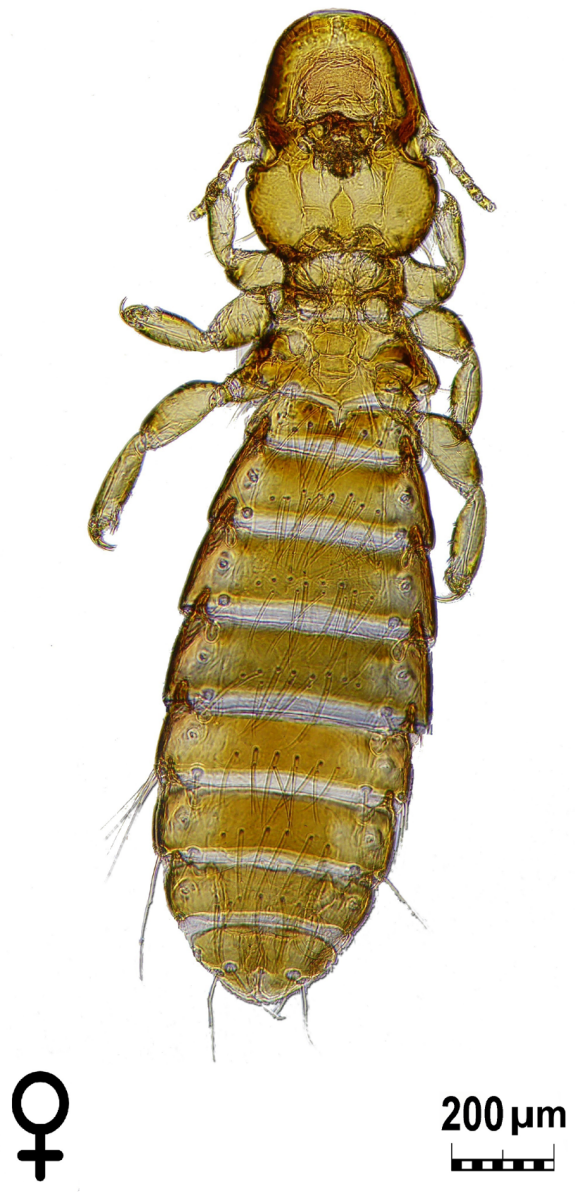

Figure 2. Degeeriella fulva. Female. Ventral view. Magnification 100X.
Colpocephalum turbinatum Denny, 1842 (Figures 3 and 4) was found on two (13.3\%) of all the Variable hawks examined. As indicated by Price et al. (2003), C. turbinatum is a cosmopolitan species parasitic on about 50 bird species of the families Accipitridae, Falconidae, Pandionidae, Strigidae and Tytonidae, as well as on the Common pigeon (Columba livia Gmelin, 1789; Columbidae). Subsequently, Martín-Mateo (2006) recorded C. turbinatum on several diurnal raptors and even on a nocturnal raptor, the Common Barn Owl (Tyto alba (Scopoli, 1769)), in Spain. Also, it has been reported parasitizing the Galápagos hawk (Buteo galapagoensis (Gould, 1837)) in the Galápagos Islands (WHITEMAN et al., 2007), the Roadside hawk (Rupornis magnirostris (Gmelin, 1788)) in Colombia (PARRA-HENAO et al., 2011), as well as in Iran (DIK \& HALAJIAN, 2013) and Pakistan (NAZ et al., 2012), confirming its cosmopolitan distribution.

In Chile, González-Acuña et al. (2008) recorded C. turbinatum from three diurnal raptors: the Rufous-tailed hawk (Buteo ventralis Gould, 1837), the Black-chested buzzard-eagle (Geranoaetus melanoleucus (Vieillot, 1819)) and the Bicolored hawk (Accipiter bicolor (Vieillot, 1819)), collected from preserved specimens held in the National Museum of Natural History in Santiago.

Nine specimens belonging to the genus Craspedorrhynchus Kéler, 1938 were collected from one (6.7\%) of the 15 Variable hawks examined (Figures 5 and 6). This genus comprises about 40 described species, all of which parasitize raptors worldwide (PRICE et al., 2003) but are absent from vultures (DIK et al.,

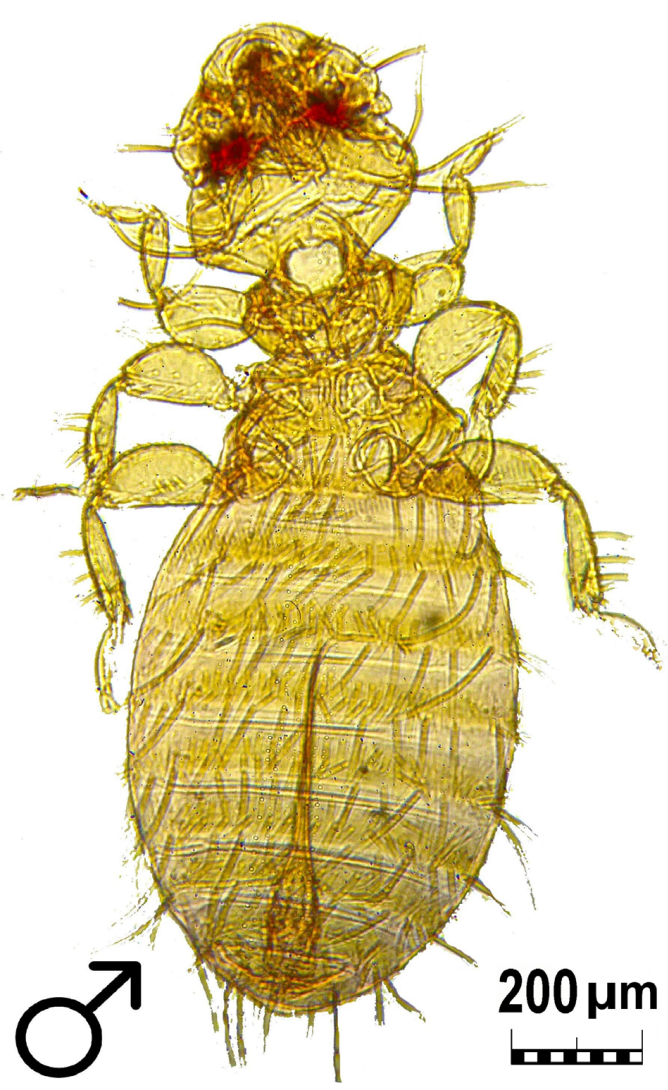

Figure 3. Colpocephalum turbinatum. Male. Ventral view. Magnification 100X. 


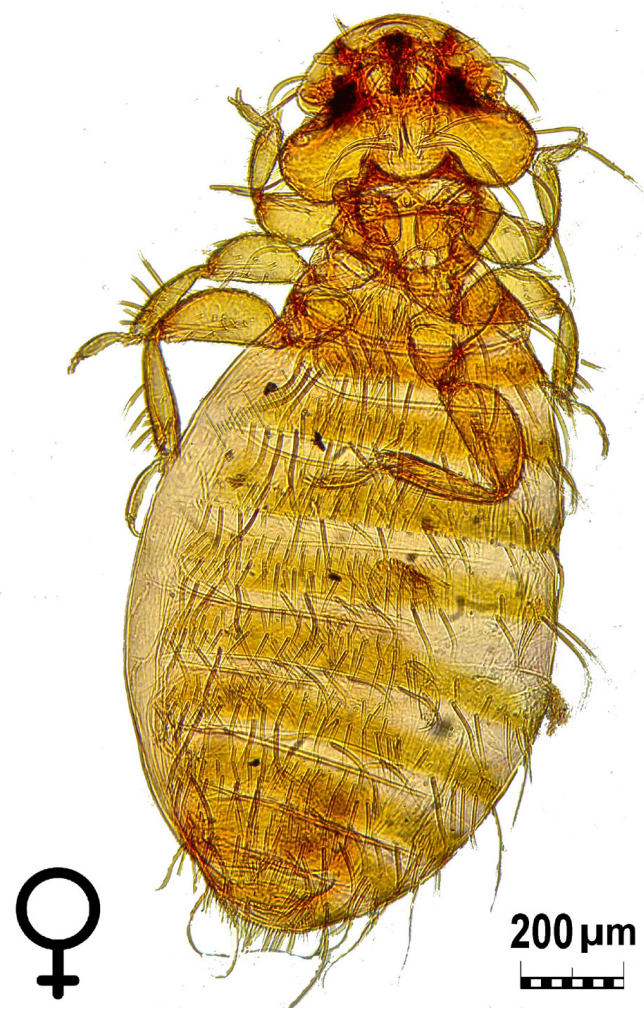

Figure 4. Colpocephalum turbinatum. Female. Ventral view. Magnification 100X.

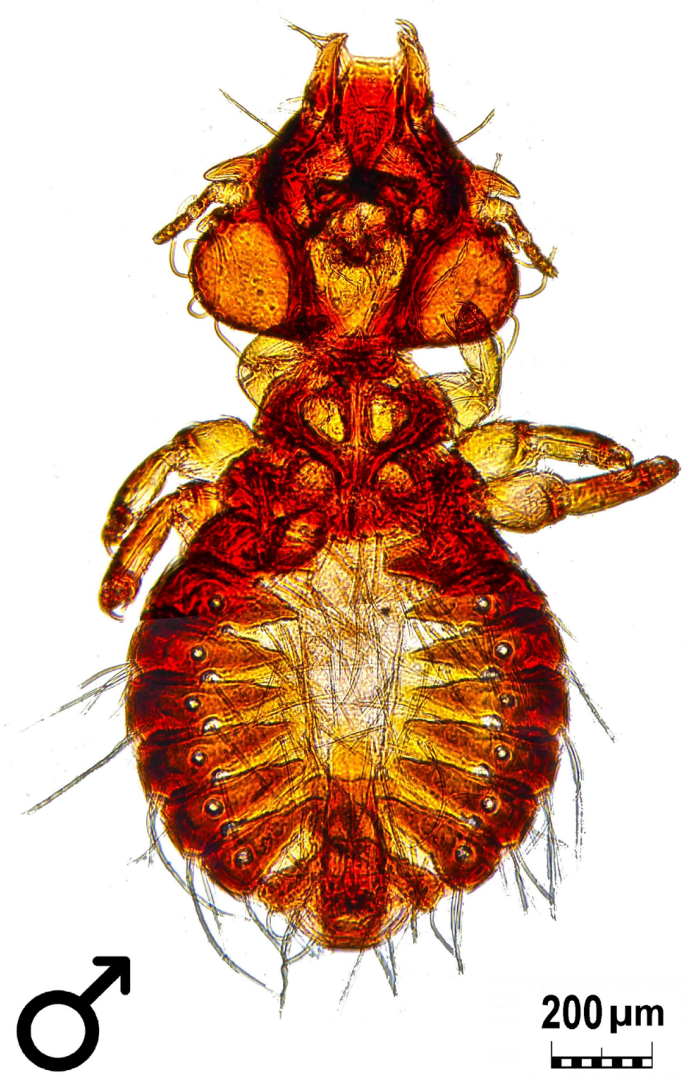

Figure 5. Craspedorrhynchus sp. Male. Ventral view. Magnification 100X.
2013). Species of Craspedorrhynchus are usually located on the head and/or neck of the host (PÉREZ \& MARTÍN-MATEO, 1995), where we also found them in this study; however, they have been collected on the thorax and wings of some birds (OLIVEIRA et al., 2011).

Subsequently to Price et al. (2003), species of Craspedorrhynchus have been reported from other members of the Accipitridae, such as Swainson's hawk (Buteo swainsoni Bonaparte, 1838) (MORISHITA et al., 2001; OLIVEIRA et al., 2011) and Buteo rufinus (Cretzschmar, 1827) (DIK, 2006). In Chile, González-Acuña et al. (2008) recorded specimens of Craspedorrhynchus sp. parasitizing Harris's hawk (Parabuteo unicinctus (Temminck, 1824)).

Ticks and mites (Acari) were not found on any of the 15 hosts examined in this study. The absence of ticks may be due to their behavior of abandoning dead hosts (NELDER \& REEVES, 2005). However, that behavior does not explain the absence of mites, which may be due to our collecting technique.

\section{Endoparasites}

We collected 14 endoparasites from three (20\%) of the 15 birds examined, as follows: 11 roundworms identified as belonging to the genus Procyrnea Chabaud, 1958 (Nematoda: Spiruroidea: Habronematidae) and three spiny-headed worms belonging to the genus Centrorhynchus Lühe, 1911 (Acanthocephala: Centrorhynchidae).

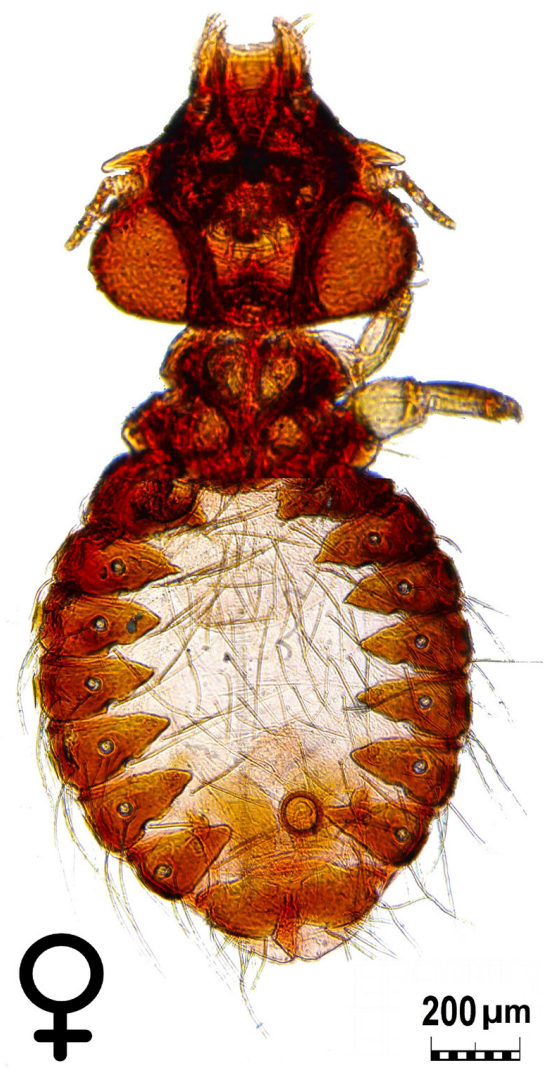

Figure 6. Craspedorrhynchus sp. Female. Ventral view. Magnification 100X. 
Roundworms of the genus Procyrnea (Figure 7) were found in two $(13.3 \%)$ of 15 of Variable hawks examined. This is a new record for the Variable hawk. The genus Procyrnea includes several species parasitic in many species of birds, including diurnal raptors in many countries (SANTORO et al., 2010; ZHANG et al., 2011; SIEGEL et al., 2012). The life cycles of species of Procyrnea require arthropods as intermediate hosts, which must be ingested by the definitive host. The final location of Procyrnea worms is in the upper gastrointestinal tract (SIEGEL et al., 2012), mainly in the glandular and muscular stomach of the birds (ARRONA-RIVERA et al., 2016). In Chile, González-Acuńa et al. (2011) reported Procyrnea sp. in specimens of the American Kestrel (Falco sparverius Linnaeus, 1758) from the city of Chillán.

Three spiny-headed worms belonging to the genus Centrorhynchus were collected in one (6.7\%) of the 15 Variable hawks. This is a new record for the Variable hawk. Centrorhynchus includes about 90 described species which parasitize a wide variety of avian hosts, being the most speciose acanthocephalan genus parasitic in birds (GOLVAN, 1994). A great number of Centrorhynchus species parasitising diurnal and nocturnal raptors were reported from Italy, Ukraine, Slovakia, USA and Ivory Coast (RICHARDSON \& NICKOL, 1995; DIMITROVA \& GIBSON, 2005; SANTORO et al., 2010, 2012; KOMOROVÁ et al., 2015; LISITSYNA \& GREBEN, 2015). In South America, there are reports of larval stages (cystacanths) of Centrorhynchus spp. from Brazil, Ecuador, Paraguay and Argentina, mainly infesting ophidians (LAMAS \& LUNASCHI, 2009; SMALES, 2007a,b; TRAVASSOS, 1926; VIZCAÍNO, 1993). In Chile, cystacanths belonging to the genus Centrorhynchus were reported in anurans of the genus Eupsophus Fitzinger 1843 (TORRES \& PUGA, 1996), which would confirm the presence of at least one type of paratenic host in this country. These acanthocephalans have a complex life cycle, infecting both diurnal and nocturnal raptors, with the first intermediate host being an isopod or an insects. Their diverse paratenic hosts (amphibians, reptiles and small mammals) have a fundamental role in their transmission to birds (BURON \& GOLVAN, 1986; OYARZÚN-RUIZ et al., 2016).

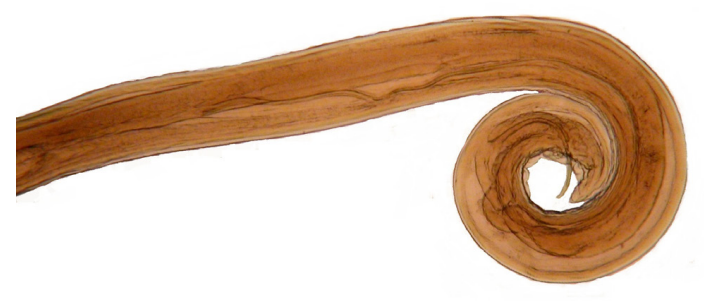

$1000 \mu \mathrm{m}$

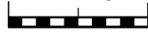

Figure 7. Procyrnea sp. Male. Magnification 100X.

\section{Conclusion}

Geranoaetus polyosoma hosts a wide diversity of parasites. Five species are recorded in this paper, including three chewing louse species (Degeeriella fulva, Colpocephalum turbinatum, Craspedorrhynchus sp.), one roundworm (Procyrnea sp.), and one spinyheaded worm (Centrorhynchus sp.). Four of those species: Craspedorrhynchus sp., Colpocephalum turbinatum, Procyrnea sp. and Centrorhynchus sp. are new records for the Variable hawk.

\section{Acknowledgements}

We are deeply grateful for the support granted by members of the National Forest Corporation (CONAF), and the Agricultural and Livestock Service (SAG) of Chile. We also thank Karen Ardiles, Sofía González, Carolina Silva and Félix Varas for their support in the field and laboratory. Sebastián Muñoz-Leal reviewed the Portuguese "Resumo". We thank Ricardo L. Palma (Museum of New Zealand, Wellington, New Zealand) for his thorough review of the original manuscript. This research study was funded to DGA by project FONDECYT, Projects 1130948 and 1170972.

\section{References}

Amin OM. Key to the families and subfamilies of Acanthocephala, with the erection of a new class (Polyacanthocephala) and a new order (Polyacanthorhynchida). J Parasitol 1987; 73(6): 1216-1219. http:// dx.doi.org/10.2307/3282307. PMid:3437357.

Arrona-Rivera AE, Sánchez-Godoy FD, Hernández-Velasco X. Proventricular parasitosis by Procyrnea sp. (Spiruroidea: Habronematidae) in a roadside hawk (Rupornis magnirostris) from the state of Veracruz, Mexico: a case report. Acta Zool Mex 2016; 32(3): 225-229.

Buron I, Golvan YJ. Les hotes des acanthocéphales. Ann Parasitol Hum Comp 1986; 61(5): 581-592.

Chabaud AG. Keys to genera of the Order Spirurida. Part 2. Spiruroidea, Habronematoidea, and Acuarioidea. Farnham Royal: Commonwealth Agricultural Bureaux; 1975.

Chester SR. A Wildlife Guide to Chile: Continental Chile, Chilean Antarctica, Easter Island, Juan Fernández Archipelago. Princeton: Princeton University Press; 2008.

Clay T. Revisions of Mallophaga genera. Degeeriella from the Falconiformes. Bull Brit Mus (Nat Hist). Entom 1958; 7(4): 121-207.

Denny H. Monographia Anoplurorum Britanniae: Henry G. Bohn 24. London; 1842.

Dik B, Halajian A, Turner M. The morphology of Craspedorrhynchus platystomus (Burmeister, 1838), a louse commonly found on the longlegged buzzard Buteo rufinus (Phthiraptera: Ischnocera: Philopteridae). Turk J Zool 2013; 37(6): 739-745. http://dx.doi.org/10.3906/zoo-1302-18.

Dik B, Halajian A. Chewing lice (Phthiraptera) of several species of wild birds in Iran, with new records. J Arthropod Borne Dis 2013; 7(1): 83-89. PMid:23785698.

Dik B. Mallophaga species on long-legged buzzards (Buteo rufinus): new records from Turkey. Turkiye Parazitol Derg 2006; 30(3): 226-230. PMid:17160858. 
Dimitrova ZM, Gibson DI. Some species of Centrorhynchus Lühe, 1911 (Acanthocephala: Centrorhynchidae) from the collection of the Natural History Museum, London. Syst Parasitol 2005; 62(2): 117-134. http:// dx.doi.org/10.1007/s11230-005-5486-7. PMid:16167121.

Dunn RR, Harris NC, Colwell RC, Koh LP, Sodhi NS. The sixth mass coextinction: are most endangered species parasites and mutualists? Proc Biol Sci 2009; 276(1670): 3037-3045. PMid:19474041.

Dunne JA, Lafferty KD, Dobson AP, Hechinger RF, Kuris AM, Martinez ND, et al. Parasites affect food web structure primarily through increased diversity and complexity. PLoS Biol 2013; 11(6): e1001579. http://dx.doi. org/10.1371/journal.pbio.1001579. PMid:23776404.

Ferguson-Lees J, Christie DA. Raptors of the world. London: Christopher Helm Publishers; 2001.

Figueroa-Rojas RA, Corales-Stappung ES, Alvarado-Orellana S. Diet of the Red-backed Hawk (Buteo polyosoma) in a forested area of the Chilean Patagonia and its relation to the abundance of rodent prey. Hornero 2003; 18(1): 43-52.

Giebel CGA. Insecta Epizoa. Leipzig: Otto Wigand; 1874.

Golvan YJ. Nomenclature of the Acanthocephala. Res Rev Parasitol 1994; 54(3): 135-205.

González-Acuña D, Ardiles K, Figueroa R RA, Barrientos C, González P, Moreno L, et al. Lice of Chilean diurnal raptors. J Raptor Res 2008; 42(4): 281-286. http://dx.doi.org/10.3356/JRR-07-69.1.

González-Acuña D, Lohse E, Cicchino A, Mironov S, Figueroa R RA, Ardiles K, et al. Parasites of the American kestrel (Falco sparverius) in south-central Chile. J Raptor Res 2011; 45(2): 188-193. http://dx.doi. org/10.3356/JRR-10-68.1.

İnc1 A, Dik B, Kibar M, Yildirim A, Duzlu O. Chewing lice (Phthiraptera) species on wild birds in Cappadocia region, Turkey. Turkiye Parazitol Derg 2010; 34(4): 174-178. http://dx.doi.org/10.5152/tpd.2010.07. PMid:21391187.

Jaramillo A. Aves de Chile: incluye la península Antártica, las Islas Malvinas y Georgia del Sur. Barcelona: Lynx; 2005.

Kinsella JM, Forrester JD. Helminths of the Florida duck, Anas platyrhynchos fulvigula. Proc Helminthol Soc Wash 1972; 38(2): 173-176.

Komorová P, Špakulová M, Hurníková Z, Uhrín M. Acanthocephalans of the genus Centrorhynchus (Palaeacanthocephala: Centrorhynchidae) of birds of prey (Falconiformes) and owls (Strigiformes) in Slovakia. Parasitol Res 2015; 114(6): 2273-2278. http://dx.doi.org/10.1007/ s00436-015-4420-4. PMid:25786606.

Lamas MF, Lunaschi LI. Primer registro de Centrorhynchus sp. (Acanthocephala: Centrorhynchidae) en Leptophis ahaetulla marginatus (Colubridae) de Argentina. Cuad Herpetol 2009; 23(1): 45-49.

Lisitsyna OI, Greben OB. Acanthocephalans of the genus Centrorhynchus (Palaeacanthocephala, Centrorhynchydae) from birds of Ukraine with the description of a new species. Vestn Zool 2015; 49(3): 195-210. http:// dx.doi.org/10.1515/vzoo-2015-0022.

Martín-Mateo MP. Diversidad y distribución de las especies de Mallophaga (Insecta) en aves y mamíferos de la comunidad de Madrid. Graellsia 2006; 62(Extra): 21-32. http://dx.doi.org/10.3989/graellsia.2006.v62.iExtra.108.

Martín-Mateo MP. Fauna Ibérica. Madrid: Museo Nacional de Ciencias Naturales - CSIC; 2009. (Phthiraptera, Ischnocera; vol. 32).

Monserrat AL, Funes MC, Novaro AJ. Respuesta dietaria de tres rapaces frente a una presa introducida en Patagonia. Rev Chil Hist Nat 2005; 78(3): 425-439. http://dx.doi.org/10.4067/S0716-078X2005000300006.
Moreno L, González-Acuña D. Los parásitos de las aves rapaces de Chile: una revisión. Bol Chil Ornitol 2015; 21(1-2): 93-102.

Morishita TY, Mertins JW, Baker DG, Monahan CM, Brooks DL. Occurrence and species of lice on free-living and captive raptors in California. J Avian Med Surg 2001; 15(4): 288-292. http://dx.doi. org/10.1647/1082-6742(2001)015[0288:OASOLO]2.0.CO;2.

Naz S, Sychra O, Rizvi SY. New records and a new species of chewing lice (Phthiraptera, Amblycera, Ischnocera) found on Columbidae (Columbiformes) in Pakistan. ZooKeys 2012; 174(174): 79-93. http:// dx.doi.org/10.3897/zookeys.174.2717. PMid:22451786.

Nelder MP, Reeves WK. Ectoparasites of road-killed vertebrates in northwestern South Carolina, USA. Vet Parasitol 2005; 129(3-4): 313322. http://dx.doi.org/10.1016/j.vetpar.2004.02.029. PMid:15845287.

Oliveira JB, Santos T, Vaughan C, Santiago H. External parasites of raptors (Falconiformes and Strigiformes): identification in an ex situ population from Mexico. Rev Biol Trop 2011; 59(3): 1257-1264. PMid:22017130.

Oyarzún-Ruiz P, Basso E, Medel J, Muñoz-Alvarado P. Parásitos: los organismos relegados de nuestra biodiversidad. Chiricoca 2016; 21: 9-15.

Palma RL. Slide-mounting of Lice: a detailed description of the Canada Balsam technique. N Z Entomol 1978; 6(4): 432-436. http://dx.doi.or $\mathrm{g} / 10.1080 / 00779962.1978 .9722313$

Parra-Henao G, Alarcón Pineda EP, López Valencia G, Ramírez Monroy DM, Jaramillo Crespo GE. Detection of ectoparasites in wild birds evaluated in Medellín (Colombia). Rev Colomb Cienc Pecu 2011; 24(1): 29-37.

Pérez JM, Martín-Mateo MP. First description of male Craspedorrhynchus subbuteonis Gallego, Martin \& Aguirre, 1987 (Phthiraptera: Ischnocera: Philopteridae). Ann Soc Entomol Fr 1995; 31(3): 285-291.

Price RD, Beer JR. Species of Colpocephalum (Mallophaga: Menoponidae) parasitic upon the Falconiformes. Can Entomol 1963; 95(7): 731-763. http://dx.doi.org/10.4039/Ent95731-7.

Price RD, Hellenthal RA, Palma RL, Johnson KP, Clayton DH. The chewing lice: world checklist and biological overview. Springfield: Illinois Natural History Survey Special Publication; 2003.

Richardson DJ, Nickol BB. The genus Centrorhynchus (Acanthocephala) in North America with description of Centrorhynchus robustus n. sp., redescription of Centrorhynchus conspectus, and a key to species.J Parasitol 1995; 81(5): 767-772. http://dx.doi.org/10.2307/3283971. PMid:7472871.

Santoro M, Mattiucci S, Nascetti G, Kinsella JM, Di Prisco F, Troisi $S$, et al. Helminth communities of owls (Strigiformes) indicate strong biological and ecological differences from birds of prey (Accipitriformes and Falconiformes) in southern Italy. PLoS One 2012; 7(12): e53375. http://dx.doi.org/10.1371/journal.pone.0053375. PMid:23300921.

Santoro M, Tripepi M, Kinsella JM, Panebianco A, Mattiucci S. Helminth infestation in birds of prey (Accipitriformes and Falconiformes) in southern Italy. Vet J2010; 186(1): 119-122. http://dx.doi.org/10.1016/j. tvjl.2009.07.001. PMid:19713134.

Siegel RB, Bond ML, Wilkerson RL, Barr BC, Gardiner CH, Kinsella JM. Lethal Procyrnea infection in a black-backed woodpecker (Picoides arcticus) from California. JZoo Wildl Med 2012; 43(2): 421-424. http:// dx.doi.org/10.1638/2011-0226.1. PMid:22779254.

Smales LR. Acanthocephala in amphibians (Anura) and reptiles (Squamata) from Brazil and Paraguay with description of a new species. $J$ Parasitol2007a; 93(2): 392-398. http://dx.doi.org/10.1645/GE-937R.1. PMid:17539424.

Smales LR. Acanthocephalans of Amphibians and Reptiles (Anura and Squamata) from Ecuador, with the description of Pandosentis napoensis 
n. sp. (Neoechinorhynchidae) from Hyla fasciata. Zootaxa 2007b; 1445(1): 49-56.

Tomás A, Palma RL, Rebelo MT, Fonseca IP. Chewing lice (Phthiraptera) from wild birds in southern Portugal. Parasitol Int 2016; 65(3): 295 301. http://dx.doi.org/10.1016/j.parint.2016.02.007. PMid:26899014.

Torres P, Puga S. Occurrence of cystacanths of Centrorhynchus sp. (Acanthocephala: Centrorhynchidae) in toads of the genus Eupsophus in Chile. Mem Inst Oswaldo Cruz 1996; 91(6): 717-719. http://dx.doi. org/10.1590/S0074-02761996000600011. PMid:9283651.

Travassos L. Contribuiçóes para o conhecimento da fauna helminthologica brasileira. XX. Revisão dos Acanthocephalos brasileiros. Parte II. Familia Echinorhynchidae Hamann, 1892, Sub-fam. Centrorhynchinae Travassos, 1919. Mem Inst Oswaldo Cruz 1926; 19(1): 31-125. http://dx.doi. org/10.1590/S0074-02761926000100003.

Trejo A, Ojeda V, Kun M, Seijas S. Prey of White-throated hawks (Buteo albigula) in the southern temperate forest of Argentina. J Field Ornithol 2006; 77(1): 13-17. http://dx.doi.org/10.1111/j.1557-9263.2006.00011.x.

Vaurie C. A systematic study of the Red-backed hawks of South America. Condor 1962; 64(4): 227-290. http://dx.doi.org/10.2307/1365367.
Vizcaíno SI. Presencia del género Centrorhynchus Lühe, 1911, (Acanthocephala: Centrorhynchidae) en la República Argentina. Neotropica 1993; 39: 77-78.

Whiteman NK, Kimball RT, Parker PG. Co-phylogeography and comparative population genetics of the threatened Galápagos hawk and three ectoparasite species: ecology shapes population histories within parasite communities. Mol Ecol 2007; 16(22): 4759-4773. http://dx.doi. org/10.1111/j.1365-294X.2007.03512.x. PMid:18028178.

Wood CL, Byers JE, Cottingham KL, Altman I, Donahue MJ, Blakeslee AM. Parasites alter community structure. Proc Natl Acad Sci USA 2007; 104(22): 9335-9339. http://dx.doi.org/10.1073/pnas.0700062104. PMid:17517667.

Yoshino T, Yanai T, Asano M, Asakawa M. First record of Porrocaecum depressum (Nematoda: Ascaridoidea), Craspedorrhynchus sp. and Degeeriella sp. (Insecta: Psocodea) obtained from a Hodgson's hawk eagle, Spizaetus nipalensis, in Gifu Prefecture, Japan. Biogeography 2012; 14: 143-148.

Zhang S, Song J, Zhang L. Three species of Procyrnea Chabaud, 1958 (Nematoda: Habronematoidea: Habronematidae) from raptors in Beijing, China, with descriptions of two new species. J Nat Hist 2011; 45(4748): 2915-2928. http://dx.doi.org/10.1080/00222933.2011.622451. 